\title{
PENGEMBANGAN MODEL LATIHAN JUMP SHOOT BOLA BASKET
}

\author{
${ }^{1}$ Rizki Yuliandra, ${ }^{2}$ Eko Bagus Fahrizqi \\ ${ }^{1,2}$ Universitas Teknokrat Indonesia \\ email : ${ }^{1}$ rizki.yuliandra@teknokrat.ac.id, ${ }^{2}$ eko.bagus@teknokrat.ac.id
}

\begin{abstract}
Abstrak
Tujuan dari penelitian dan pengembangan ini adalah untuk menghasilkan model latihan jump shoot bola basket yang baru. Selain itu, penelitian dan pengembangan ini dilakukan untuk memperoleh informasi secara mendalam tentang pengembangan dan penerapan model latihan jump shoot dan mengetahui efektivitas, efisiensi dan daya tarik hasil pengembangan model latihan ini. Penelitian dan pengembangan ini menggunakan pendekatan kualitatif serta menggunakan metode Penelitian Pengembangan (Research \& Development) dari Borg and Gall. Subjek dalam penelitian dan pengembangan ini adalah anggota UKM Basket Teknokrat yang berjumlah 30 0rang. Instrumen yang digunakan dalam penelitian dan pengambangan ini berupa kuesioner dan angket, yang digunakan untuk mengumpulkan data pada tahap: (1) analisis kebutuhan; (2) evaluasi ahli ; (3) ujicoba kelompok kecil; dan (4) ujicoba lapangan.Tes efektivitasnya adalah hasil validasi dari 3 ahli dan hasil tes uji lapangan. Hasil dari 3 ahli menyatakan bahwa 82,8\% layak digunakan dan uji kecil menyatakan 80,8\% sangat layak digunakan. Berdasarkan hasil penelitian dan pengembangan dapat disimpulkan bahwa: (1) Dengan pengembangan model latihan jump shoot ini, dapat membantu siswa dalam meningkatkan keterampilan jump shoot bola basket. (2) Memberikan referensi baru latihan jump shoot bola basket.
\end{abstract}

Kata Kunci: Pengembangan, Model Latihan, Bola Basket.

\begin{abstract}
The purpose of this research and development is to produce a new basketball jump shoot training model. In addition, this research and development is conducted to obtain information in depth about the development and implementation of jump shoot training model and to know the effectiveness, efficiency and attractiveness of the development of this model of exercise. This research and development uses a qualitative approach and using Research Development (Development \& Development) method from Borg and Gall. Subjects in research and development is a member of UKM Basket Teknokrat amounted to 30 subjects. The instruments used in this research and mining are questionnaires, which are used to collect data in the following stages: (1) needs analysis; (2) expert evaluation; (3) small group trial; and (4) field test. The effectiveness test is validation result from 3 experts and field test result. Results from 3 experts stated that $82.8 \%$ was feasible to use and a small test stated $80.8 \%$ was very feasible to use. Based on the results of research and development can be concluded that: (1) With the development of this jump shoot training model, can help students in improving skill jump shoot basketball. (2) Provide a new reference to jump shoot basketball training.
\end{abstract}

Keywords: Development, Exercise Model, Basketbal 


\section{Pendahuluan}

Pendidikan jasmani termasuk mata pelajaran di sekolah sebagai media yang mendorong perkembangan motorik, kemampuan fisik, pengetahuan penalaran, penghayatan nilai (sikap, mental, emosional, spritual, sosial), membantu siswa memahami mengapa manusia bergerak dan bagaimana cara melakukan gerak secara aman, efisien, efektif sehingga menghargai manfaat aktivitas jasmani bagi peningkatan kualitas hidup dan pembiasaan pola hidup sehat yang bermuara untuk merangsang pertumbuhan dan perkembangan yang seimbang. Di dalam kurikulum pendidikan jasmani siswa diharapkan memiliki kebugaran jasmani yang memadai, menguasai paling tidak salah satu nomor atletik, senam, beladiri, renang, dan olahraga permainan sehingga peserta didik mempunyai kepercayaan diri untuk melakukan kegiatan olahraga secara teratur, memiliki gaya hidup aktif karena didukung oleh pengetahuan yang memadai tentang pendidikan jasmani, peraturan teknis dan taktis serta strategi olahraga.

Menurut Setyo Budiwanto di dalam pendidikan jasmani, terdapat dua jenis permainan yaitu permainan bola besar yang terdiri dari sepak bola, bola voli, dan bola basket, sedangkan permainan bola kecil terdiri dari bulu tangkis, tenis meja, takraw, softball. Salah satu permainan bola besar yakni bola basket. Melalui permainan bola basket diharapkan akan meningkatkan kesegaran jasmani, kesehatan, meningkatnya watak disiplin serta untuk meningkatkan kepercayaan diri melakukan olahraga secara teratur.

Hampir di setiap sekolah memiliki kegiatan pendukung ekstrakulikuler kecabangan olahraga, bagi siswa-siswi yang memiliki minat dan bakat dalam suatu cabang olahraga tertentu dapat mengikuti kegiatan ekstrakulikuler di sekolah. Olahraga juga dapat dijadikan sebagai rekreasi dan sarana mengembangkan prestasi diri seperti yang disebutkan dalam UUD RI nomor 3 tentang sistem keolahragaan nasional.Salah satu ekstrakulikulernya adalah klub bola basket yang ada di sekolah. Siswasiswi dapat menambah porsi latihan bola basket di karenakan kurangnya waktu pada saat jam pelajaran pendidikan jasmani. Dalam permainan bola basket selain sebagai peningkatan kesegaran jasmani dan kesehatan masih memiliki suatu tujuan yang harus dicapai yaitu meraih prestasi dalam bidang olahraga bola basket.

Danny Kosasih menyebutkan kemenangan dalam suatu pertandingan merupakan suatu prestasi dalam bidang olahraga, mencapai kemenangan dengan menciptakan point (nilai) sebanyak-banyaknya. Untuk dapat menciptakan point sangat dibutuhkan kerja sama antar pemain, akan dapat terlaksana dengan baik apabila seluruh pemain yang ikut dalam pertandingan tersebut telah memiliki teknik yang baik pula. Dalam permainan bola basket ada beberapa teknik dasar yang wajib dikuasai, yaitu drible, passing, dan jump shoot. Untuk menghasilkan point (nilai) dalam permainan bola basket kita harus memasukkan bola ke dalam keranjang lawan yang biasa disebut jump shoot. Jump shoot dapat dilakukan dengan cara menembakkan bola ke arah ring (Oliver, Jon. Dasar dasar bola basket. 2007)

Melalui pengamatan yang dilakukan di beberapa event atau kompetisi bola basket di Provinsi Lampung, di dapatkan hasil yaitu buruknya kualitas jump shoot para pemain dalam mengoptimalkan kesempatan mencetak poin 
dikarenakan tidak terlalu menguasai teknik jump shoot yang baik. Dalam pembelajaran pendidikan jasmani, masih banyak dijumpai permasalahanpermasalahan yang di temukan, seperti dalam hal pemahaman para pelatih terhadap bentuk latihan yang tepat dan efektif untuk dipergunakan dalam melatih keterampilan teknik dasar bola basket. Jelas sangatlah memprihatinkan apabila kondisi semacam itu terus berlanjut, sebab bagaimana seorang pendidik akan dapat merancang model latihan dengan baik. Untuk itu calon peneliti ingin melakukan pengembangan bentuk latihan terhadap jump shoot bola basket

II. BAHAN DAN METODE/METODOLOGI

\section{1 Ruang Lingkup Penelitian}

Sebelum memulai penelitian, peneliti menentukan komponen dari ruang lingkup penelitian. Nusa Putra menyebutkan ada 3 komponen ruang lingkup yaitu, objek, subjek dan tempat penelitian.

1. Obyek Penelitian : Untuk menciptakan model latihan jump shoot bola basket yang baru

2. Subyek penelitian : Anggota UKM Basket Teknokrat berjumlah 30 orang

3. Tempat : Gelanggang Olahraga Mahasiswa Teknokrat

\subsection{Metode Penelitian}

Penelitian dan pengembangan (R\&D), merupakan metode penelitian yang digunakan untuk mengembangkan atau menvalidasi produk-produk yang digunakan dalam pendidikan dan pembelajaran. Menurut sugiono terdapat produk-produk pendidikan seperti kurikulum yang spesifik untuk keperluan pendidikan tertentu, metode pembelajaran, media pembelajaran, buku ajar, modul, kompetensi tenaga kependidikan, sistem evaluasi, model uji kompetensipenataan ruang kelas untuk pembelajaran tertentu dan lain-lain.

Penelitian ini menggunakan pendekatan kualitatif dan kuantitatif, yang merupakan pendekatan dengan tujuan menemukan jawaban dari masalah melalui rumusan masalah yang telah dirumuskan yaitu model latihan shooting bola basket. Penelitian dan pengembangan ini menggunakan pendekatan kualitatif dan kuantitatif serta menggunakan model pengembangan Research\& Development ( $R \& D$ ) dari Borg dan Gall yang terdiri dari sepuluh langkah. Tujuan akhir dari penelitian dan pengembangan ini adalah terciptanya model latihan shooting bola basket.

\subsection{Rancangan Penelitian}

Untuk perancangan produk pengembangan bentuk latihan jump shoot bola basket untuk anggota UKM bola basket Teknokrat dikutip dari Borg and Gall dalam Sugiyono memiliki langkah-langkah sebagai berikut:

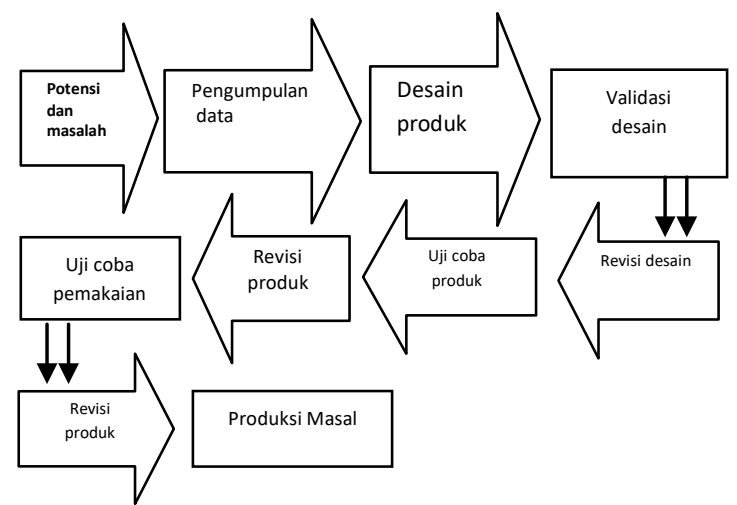

Gambar 1 : Model Pengembangan R\&D

Sumber : Sugiyono, Metode Penelitian Pendidikan, Pendekatan Kuantitatif, Kualitatif, dan R\&D, 2009, h.298

\section{Hasil dan PeMbahasan}

Penyebaran angket untuk analisis kebutuhan dalam penelitian pengembangan model latihan jump 
shoot bola basket ini melibatkan 30 anggota unit kegiatan mahasiswa basket Universitas Teknokrat Indonesia. Analis kebutuhan dilakukan dengan cara menyebarkan angket analisis kebutuhan yang berisi pertanyaan-pertanyaan yang bertujuan untuk mengetahui dibutuhkan atau tidaknya model latihan ini.

Tabel. Data Hasil Analisis

Kebutuhan Subjek

\begin{tabular}{|c|c|c|c|c|c|}
\hline No & Pertanyaan & $\begin{array}{l}\text { Skor } \\
\text { Min }\end{array}$ & $\begin{array}{l}\text { Skor } \\
\text { Max }\end{array}$ & $\begin{array}{l}\text { Skor } \\
\text { Hasil }\end{array}$ & $\%$ \\
\hline 1 & $\begin{array}{l}\text { Apakah } \\
\text { anda tahu } \\
\text { tentang } \\
\text { jump shoot } \\
\text { bola basket } \\
\text { ? }\end{array}$ & 30 & 120 & 75 & 63 \\
\hline 2 & $\begin{array}{l}\text { Apakah } \\
\text { latihan } \\
\text { Jump shoot } \\
\text { di sekolah } \\
\text { anda } \\
\text { membosank } \\
\text { an? }\end{array}$ & 30 & 120 & 68 & 57 \\
\hline
\end{tabular}

pelatih

sudah

menggunak

$\begin{array}{llllll}3 & \text { an berbagai } & 30 & 120 & 68 & 57\end{array}$

model

latihan

Jump shoot

?

Apakah

waktu

pelaksanaan

kegiatan

$\begin{array}{llllll}4 & \text { ekstrakuliku } & 30 & 120 & 70 & 58\end{array}$

ler di

sekolah

sudah

cukup ?

Apakah

anda setuju

apabila

peserta

5 ekstrakuliku $30 \quad 120 \quad 75 \quad 62$

ler

diberikan

latihan jump

shoot?

\begin{tabular}{|c|c|c|c|c|c|}
\hline 6 & $\begin{array}{l}\text { Setujukah } \\
\text { jump shoot } \\
\text { merupakan } \\
\text { teknik yang } \\
\text { harus } \\
\text { dikuasai } \\
\text { oleh siswa? }\end{array}$ & 30 & 120 & 80 & 67 \\
\hline .7 & $\begin{array}{l}\text { Apakah } \\
\text { pelatih } \\
\text { harus } \\
\text { memberika } \\
\text { n latihan } \\
\text { yang } \\
\text { variatif } \\
\text { terhadap } \\
\text { latihan } \\
\text { shooting? }\end{array}$ & 30 & 120 & 84 & 70 \\
\hline 8 & $\begin{array}{l}\text { Setujukah } \\
\text { bila latihan } \\
\text { jump shoot } \\
\text { diperlukan } \\
\text { variasi } \\
\text { latihan? }\end{array}$ & 30 & 120 & 88 & 73 \\
\hline 9 & $\begin{array}{l}\text { Setujukah } \\
\text { apabila } \\
\text { dilakukan } \\
\text { pengemban } \\
\text { gan model } \\
\text { latihan jump } \\
\text { shoot bagi } \\
\text { siswa? }\end{array}$ & 30 & 120 & 92 & 77 \\
\hline 10 & $\begin{array}{l}\text { Setujukah } \\
\text { apabila } \\
\text { model } \\
\text { latihan yang } \\
\text { bervariasi } \\
\text { akan } \\
\text { meningkatk } \\
\text { an } \\
\text { kemampuan } \\
\text { jump shoot } \\
\text { ? }\end{array}$ & 30 & 120 & 80 & 67 \\
\hline \multicolumn{5}{|c|}{ TOTAL } & $\begin{array}{c}65 \\
1\end{array}$ \\
\hline
\end{tabular}

Berdasarkan tabel hasil data analisis kebutuhan di atas maka didapatkan hasil sebesar $\mathbf{6 5 , 1 \%}$ menyatakan setuju apabila diadakan pengembangan terhadap model latihan jump shoot bola basket.

Tabel. Rekapitulasi Data Hasil Uji Kelompok Kecil

\begin{tabular}{llllll}
\hline No & Indikator & Skor & Skor & Skor & Present \\
\hline
\end{tabular}




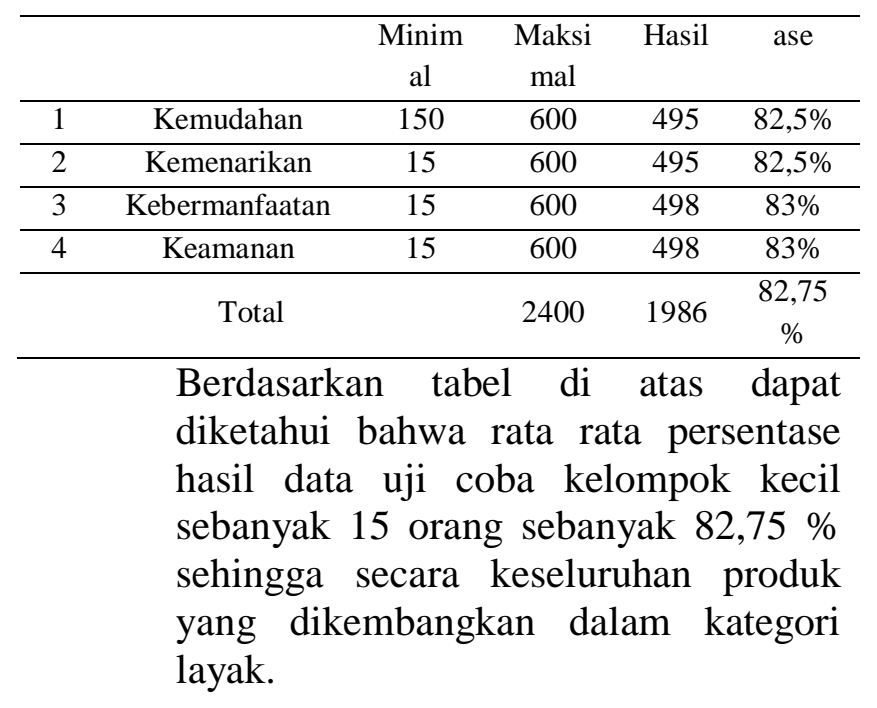

\section{KESIMPULAN DAN SARAN}

\section{Kesimpulan}

1. Berdasarkan validasi para ahli dan uji coba, telah dihasilkan suatu produk model latihan jump shoot bola basket yang ternyata secara keseluruhan layak digunakan. Hal ini berdasarkan pada pembahasan hasil analisis uji coba produk, yang meliputi indikator kemudahan, kemenarikan, kebermanfaatan, dan keamanan.

2. Berdasarkan hasil uji coba efektivitas model, terbukti secara empiris bahwa hasil produk yang berupa model latihan jump shoot bola basket ini memiliki efektifitas yang sangat baik. Hal itu berdasarkan dari hasil tes keterampilan jump shoot bola basket yang menunjukkan bahwa harga rata-rata hasil posttest lebih besar daripada rata-rata hasil pretest. Sehingga dapat dinyatakan bahwa, model latihan ini efektif untuk meningkakan hasil latihan keterampilan jump shoot bola basket.

\section{Saran}

Dalam mengembangkan penelitian ini ke arah lebih lanjut, peneliti mempunyai beberapa saran, sebagai berikut :

1. Untuk subyek penelitian sebaiknya dilakukan pada subyek yang lebih luas, baik itu dari jumah subyek maupun jumlah kelompok yang digunakan sebagai kelompok uji coba.

2. Hasil pengembangan model latihan jump shoot bola basket ini dapat disebarluaskan ke seluruh guruguru pendidikan jasmani di Indonesia dan pelatih bola basket

\section{Daftar Pustaka}

Budiwanto,Setyo. Metodologi Kepelatihan Olahraga. Malang: UM Press. 2011

Kosasih, Danny. Fundamental Basketball. Semarang : Karangturi Media. 2008

Oliver, Jon. Dasar-dasar Bola Basket. Kementrian Pemuda Olahraga. 2007

Putra, Nusa. Research \& Development. Jakarta: Rajawali Pers. 2012

Sugiyono, Metode Penelitian Pendidikan, Pendekatan Kuantitatif, Kualitatif, dan R\&D, 2009 